\title{
SMR
}

\section{Selection in sugarcane based on inbreeding depression}

\author{
A.A.C. de Azeredo ${ }^{1}$, L.L. Bhering ${ }^{1}$, B.P. Brasileiro ${ }^{2}$, C.D. Cruz $^{1}$ and \\ M.H.P. Barbosa ${ }^{3}$ \\ ${ }^{1}$ Departamento de Biologia Geral, Universidade Federal de Viçosa, \\ Viçosa, MG, Brasil \\ ${ }^{2}$ Departamento de Estatística, Universidade Federal de Viçosa, \\ Viçosa, MG, Brasil \\ ${ }^{3}$ Departamento de Fitotecnia, Universidade Federal de Viçosa, \\ Viçosa, MG, Brasil \\ Corresponding author: A.A.C. de Azeredo \\ E-mail: afonso@agronomo.eng.br \\ Genet. Mol. Res. 15 (2): gmr.15027965 \\ Received October 30, 2015 \\ Accepted December 10, 2015 \\ Published May 25, 2016 \\ DOI http://dx.doi.org/10.4238/gmr.15027965
}

\begin{abstract}
This study aimed to evaluate the gene action associated with yield-related traits, including mean stalk weight (MSW), tons of sugarcane per hectare (TCH), and fiber content (FIB) in sugarcane. Moreover, the viability of individual reciprocal recurrent selection (RRSI-S1) was verified, and the effect of inbreeding depression on progenies was checked. The results were also used to select promising genotypes in S1 progenies. Eight clones (RB925345, RB867515, RB739359, SP80-1816, RB928064, RB865230, RB855536, and RB943365) and their respective progenies, derived from selfing (S1), were evaluated. Several traits, including the number of stalks, MSW, soluble solids content determined in the field, stalk height, stalk diameter, $\mathrm{TCH}$, soluble solids content determined in the laboratory, sucrose content, and FIB were evaluated in a randomized block design with hierarchical classification. The results showed that the traits with predominant gene action associated with the dominance variance of
\end{abstract}


MSW and TCH were most affected by inbreeding depression. The FIB, with predominant additive control, was not affected by selfing of the clones, and the RB $867515 \otimes, \mathrm{RB} 928064 \otimes, \mathrm{RB} 739359 \otimes$ and $\mathrm{RB} 925345 \otimes$ progenies performed best. Therefore, the use of $\mathrm{S} 1$ progenies for RRSI-S1 in sugarcane breeding programs is promising, and it should be explored for the future breeding of clones with high FIB levels.

Key words: Plant breeding; Quantitative genetics; Saccharum spp; Recurrent selection; Self-fertilization

\section{INTRODUCTION}

To meet the growing demand for new sugarcane clones, the inheritance of agronomic traits should be investigated to define the best breeding strategy. Because of the perennial characteristic of sugarcane, breeding programs should be able to generate new clones during populational and interpopulational breeding stages. Recurrent selection is the best way to develop new clones and to obtain long-term gains in the program (Resende, 2002), and individual and reciprocal selection are the two main forms of recurrent selection. Individual selection exploits the additive effects, while reciprocal selection focuses on the improvement of interpopulational hybrids based on additive genetic values and heterosis (Resende, 2002).

The use of selfed progenies (S1) associated with the reciprocal recurrent selection of individual plants is a promising strategy to increase the additive genetic variation of a population and to subsequently exploit heterosis in interpopulation crosses.

Reciprocal recurrent selection of individuals (RRSI-S1) includes the selection of clones derived from hybrid progeny and the recombination of selfing (S1), with the simultaneous formation of hybrids associated with clones, prior to the establishment of the new experimental hybrid population (Resende and Barbosa, 2005). The goal of RRSI-S1 is to eliminate deleterious alleles from the population by selecting transgressive individuals from progenies and to increase the genetic variance among populations.

Reciprocal recurrent selection (SSR) is the most exploited strategy in breeding programs, but studies of RRSI-S1 in sugarcane are scarce. The establishment of the first S1 generation is initiated by selfing of the clones. S1 progeny plants are subsequently selected for future interpopulational crosses and recombination at the population level (Resende, 2002; Resende and Barbosa, 2005). Studies by Ferreira et al. (2005) and Silva and Gonçalves (2011) indicated the possibility of potential clone selection among S1 sugarcane progenies.

The objectives of this study were: 1) to evaluate the gene action of yield-related traits, including mean stalk weight (MSW), tons of sugarcane per hectare (TCH), and fiber content (FIB) in sugarcane; 2) to assess the viability of RRSI-S1;3) to determine the effect of inbreeding depression on S1 progenies; and 4) to select promising genotypes among the S1 clones.

\section{MATERIAL AND METHODS}

\section{Plant material}

There were 16 total treatments, including eight clones (RB925345, RB867515, RB739359, SP80-1816, RB928064, RB865230, RB855536, and RB943365) and their 
respective progenies, which were obtained by selfing ( $\mathrm{S} 1$; denoted by the $\otimes$ symbol). The $\mathrm{S} 1$ progenies were established in 2010 at the Experimental Station of Serra do Ouro of the Federal University of Alagoas in the Municipality of Murici, AL.

After acclimation, seedlings grown from selfed seeds were used to install the experiment at the Sugarcane Breeding Research Center (Centro de Pesquisa e Melhoramento de Cana-de-Açúcar - CECA) of the Federal University of Viçosa in the municipality of Oratorios, $\mathrm{MG}$ (latitude: $20^{\circ} 25^{\prime} \mathrm{S}$; longitude: $42^{\circ} 48^{\prime} \mathrm{W}$; $494 \mathrm{~m}$ asl.).

The eight clones and their respective selfed progenies were evaluated using a randomized block design with seven replications. Each replication plot consisted of two 6-m long furrows that were spaced $1.40 \mathrm{~m}$ apart. In the furrows containing progenies, 12 seedlings were planted at a spacing of $0.5 \mathrm{~m}$, and 18 buds were planted per meter in the furrows containing clones.

\section{Phenotypic evaluation}

The following traits were evaluated one year after the first sugarcane cut (at the ratoon stage): number of stalks (NS), the total number of stalks in the plot; MSW (kg); stalk height $(\mathrm{m}$; SH); and mean stalk diameter (cm; SD). Regarding the clones, NS was calculated per meter by counting all of the stalks per plot. To evaluate SH and SD in the clones, 15 stalks per plot were randomly sampled for weighing and measurements. In the progenies, SH and SD were evaluated by measuring three stalks per plant in the plot, and MSW was evaluated by weighing 15 stalks per plot. TCH was estimated using the following equation:

$$
\mathrm{TCH}=[(\mathrm{MSW} \times \mathrm{NS}) \times 10] / \mathrm{tp} \quad \text { (Equation 1) }
$$

where tp is the plot area in $\mathrm{m}^{2}$. FIB, soluble solids content determined in laboratory (SSL), and sucrose content in percentage (SC) were estimated from analyses of 500-g samples of crushed sugarcane from 10 stalks per plot using the technical analysis methodology of Fernandes (2011). The soluble solids content measured in the field (SSF) was obtained from one stalk per sugarcane stool per progeny from all plots. Regarding the clones, SSF was determined using samples from the upper third of the stalks from three plants per plot, and readings were conducted using a hand-held refractometer.

\section{Mass selection}

In June 2012, mass selection within progenies was carried out to advance the best genotypes to the second test phase (T2). After two years of evaluation of the genotypes selected in the initial population (both sugarcane plant and ratoon), also known as the first test phase (T1), the second selection cycle was conducted in May 2014. This second selection cycle was used to advance the best genotypes to the third test phase (T3) of the sugarcane breeding program at the Federal University of Viçosa (PMGCA/UFV).

\section{Data analysis}

Data analysis and genetic parameter estimates were conducted using the GENES software (Cruz, 2013), according to the following statistical model: 


$$
\mathrm{Y}_{\mathrm{ljk}}=\mu+\mathrm{A}_{1}+\mathrm{G} / \mathrm{A}_{\mathrm{ijk}}+\mathrm{B}_{\mathrm{k}}+\mathrm{E}_{\mathrm{ijk}}
$$

(Equation 2)

where is the mean observed in genotype $\mathrm{j}$ in group $\mathrm{i}$ in block $\mathrm{k} ; \mu$ is the fixed effect of the overall mean; is the random effect of the group (progeny or clone); is the random effect of the block; is the random effect of the jth genotype within the ith group; and is the random effect of the experimental error associated with the plot of block $\mathrm{k}$, in which genotype $\mathrm{j}$ grew under condition $\mathrm{i}$. The means were grouped by the Scott-Knott test, which was modified by Bhering et al. (2008). The number of superior S1 clones was obtained by counting the number of progenies with higher general means than their respective parent, and the means of each trait were ordered to establish a descending ranking $(R)$ for each trait. The ranks $(R)$ were summed in order, and their sum was calculated. The sum of ranks (SR) was ordered from the lowest to the highest sum, constituting the overall performance (OP). The mean inbreeding depression (ID) was calculated using the following equation as proposed by Silva and Gonçalves:

$$
\mathrm{ID}(\%)=[(\mathrm{P} 1-\mathrm{S} 1) / \mathrm{P} 1] \times 100
$$

(Equation 3)

where P1 is the parent mean; and S1 is the progeny mean. The estimated ID of each trait was ranked (R), so that the best-ranked characters were those with the lowest ID percentage. The same methods used to evaluate the means of the SI traits were applied to the rankings.

\section{RESULTS AND DISCUSSION}

Based on the results of the analysis of variance (ANOVA), the treatments (clone + progeny) and groups (of clones and progenies) were significantly different $(\mathrm{P}<0.05)$ for all traits. Moreover, there was a significant difference for treatments within groups $(\mathrm{P}<0.001)$ for most traits, with the exception of SH and SC. Regarding the treatments within clones, only mean stalk length, SSL, and SC were not significantly different (Table 1). Based on these results, no behavioral differences were detected between clones and their progenies for traits related to higher sugar content (e.g., SSL and SC). Higher variability was found in biomass production traits (e.g., NS and MSW).

Table 1. Analysis of variance (ANOVA), overall mean, and coefficient of variation results for the nine traits
examined.
\begin{tabular}{l|c|c|c|c|c|c|c|c|c|c}
\hline SV & d.f. & NS & MSW & SSF & SH & SD & TCH & SSL & SC & FIB \\
\hline Blocks & 6 & 0.36 & 0.04 & 2.34 & 0.01 & 0.02 & 112.14 & 1.86 & 1.38 & 0.34 \\
\hline Treatments & 15 & $1.90^{\text {ns }}$ & $0.61^{* *}$ & $9.81^{* *}$ & $0.12^{*}$ & $0.38^{* *}$ & $2,188.98^{* *}$ & $4.25^{* *}$ & $6.98^{* *}$ & $3.19^{* *}$ \\
\hline Groups & 1 & $5.03^{* *}$ & $5.46^{* *}$ & $97.31^{* *}$ & $0.48^{* *}$ & $3.99^{* *}$ & $15,794.57^{* *}$ & $35.66^{* *}$ & $77.92^{* *}$ & $9.70^{* *}$ \\
\hline Genot/group & 14 & $1.68^{* *}$ & $0.26^{* *}$ & $3.56^{* *}$ & $0.10^{\text {ns }}$ & $0.12^{* *}$ & $1,217.16^{* *}$ & $2.01^{* *}$ & $1.91^{\text {ns }}$ & $2.73^{* *}$ \\
\hline Genot/clone & 7 & $0.78^{* *}$ & $0.15^{* *}$ & $1.35^{\text {ns }}$ & $0.03^{\text {ns }}$ & $0.07^{* *}$ & $565.34^{*}$ & $1.01^{\text {ns }}$ & $1.28^{\text {ns }}$ & $3.96^{* *}$ \\
\hline Genot/progeny & 7 & $2.57^{* *}$ & $0.36^{* *}$ & $5.75^{* *}$ & $0.16^{* *}$ & $0.17^{* *}$ & $1,868.98^{* *}$ & $2.99^{*}$ & $2.53^{\text {ns }}$ & $1.50^{\text {ns }}$ \\
\hline Residue & 90 & 0.26 & 0.04 & 0.91 & 0.06 & 0.02 & 201.32 & 99.27 & 1.24 & 0.71 \\
\hline Mean & & 4.53 & 1.37 & 19.61 & 2.18 & 2.71 & 70.13 & 18.98 & 14.39 & 10.38 \\
\hline CV (\%) & & 11.29 & 15.13 & 4.86 & 11.10 & 5.03 & 20.23 & 5.53 & 7.74 & 8.16 \\
\hline Traits
\end{tabular}

Traits examined: number of stalks (NS), mean stalk weight (MSW), soluble solids content in field (SSF), stalk height (SH), stalk diameter (SD), tons of sugarcane per hectare (TCH), soluble solids determined in laboratory (SSL), sucrose content (SC), and fiber content (FIB). ns,****Values that are non-significant, significant at $5 \%$ probability, and significant at $1 \%$ probability, respectively, based on the $\mathrm{F}$ test. 
The coefficients of overall experimental variation $\left(\mathrm{CV}_{\mathrm{e}}\right)$ for the nine traits studied ranged from 4.86 to $20.23 \%$, and these values were considered low to medium according to Pimentel (1990), indicating good experimental accuracy (Table 1).

The $\mathrm{CV}_{\mathrm{e}}$ values for the progenies were higher than those of the clones (Table 2), with the exception of FIB, which exhibited values of 7.93 and $8.40 \%$ for clones and progenies, respectively. An increase in $\left(\mathrm{CV}_{\mathrm{e}}\right)$ was expected in progenies, because selfing typically reduces the mean. Moreover, as the standard deviation increases, higher coefficients of environmental variation result.

Table 2. Values of maximum (MAX), minimum (MIN), mean (MED), experimental coefficient of variation $\left(C V_{e}\right)$, coefficient of genetic variation $\left(\mathrm{CV}_{\mathrm{g}}\right)$, genetic variance $\widehat{\sigma}_{\mathrm{g}}^{2}$, heritability $\left(\mathrm{h}^{2}(\%)\right)$, and ratio of coefficient of genetic and environmental variation for clones (c) and selfings (s) for the examined traits.

\begin{tabular}{|c|c|c|c|c|c|c|c|c|c|c|}
\hline SV & & NS & MSW & SSF & $\mathrm{SH}$ & SD & $\mathrm{TCH}$ & SSL & SC & FIB \\
\hline \multirow[t]{2}{*}{ Max } & $\mathrm{C}$ & 6.80 & 2.34 & 22.80 & 2.782 & 3.51 & 127.24 & 21.60 & 17.86 & 12.66 \\
\hline & $\mathrm{S}$ & 5.78 & 1.74 & 20.10 & 2.975 & 2.96 & 108.27 & 20.60 & 15.69 & 12.79 \\
\hline \multirow[t]{2}{*}{ Min } & C & 3.75 & 0.96 & 17.00 & 1.90 & 2.44 & 44.56 & 16.80 & 11.67 & 7.90 \\
\hline & $\mathrm{S}$ & 2.37 & 0.73 & 16.26 & 1.65 & 2.21 & 19.48 & 14.10 & 10.08 & 8.60 \\
\hline \multirow[t]{2}{*}{ Med } & C & 4.74 & 1.60 & 20.54 & 2.24 & 2.90 & 82.01 & 19.55 & 15.22 & 10.09 \\
\hline & $\mathrm{S}$ & 4.32 & 1.16 & 18.68 & 2.11 & 2.52 & 58.26 & 18.42 & 13.55 & 10.68 \\
\hline \multirow[t]{2}{*}{$C V_{e}(\%)$} & $\mathrm{C}$ & 10.79 & 13.03 & 4.63 & 10.78 & 4.71 & 17.30 & 5.37 & 7.32 & 8.40 \\
\hline & $\mathrm{S}$ & 11.85 & 18.01 & 5.10 & 11.45 & 5.41 & 24.36 & 5.70 & 8.22 & 7.93 \\
\hline \multirow[t]{2}{*}{$C V_{g}(\%)$} & $\mathrm{C}$ & 6.01 & 8.97 & 1.29 & 0.00 & 3.32 & 10.28 & 0.00 & 0.55 & 6.55 \\
\hline & $\mathrm{S}$ & 12.69 & 15.56 & 4.24 & 5.78 & 5.46 & 22.00 & 2.74 & 2.99 & 3.22 \\
\hline \multirow[t]{2}{*}{$\widehat{\sigma}_{g}^{2}$} & C & 0.08 & 0.01 & 0.06 & 0.00 & 0.01 & 52.00 & -0.01 & 0.01 & 0.46 \\
\hline & $\mathrm{S}$ & 0.33 & 0.05 & 0.69 & 0.02 & 0.02 & 238.00 & 0.27 & 0.18 & 0.11 \\
\hline \multirow[t]{2}{*}{$h^{2}(\%)$} & C & 66.42 & 71.11 & 33.06 & 0.00 & 75.24 & 64.39 & 0.00 & 3.38 & 81.86 \\
\hline & $\mathrm{S}$ & 89.83 & 88.10 & 84.25 & 65.49 & 89.16 & 89.23 & 63.20 & 51.04 & 52.17 \\
\hline \multirow[t]{2}{*}{$C V_{g} / C V_{e}$} & $\mathrm{C}$ & 0.53 & 0.59 & 0.27 & 0.00 & 0.66 & 0.51 & 0.00 & 0.07 & 0.80 \\
\hline & $\mathrm{S}$ & 1.12 & 1.03 & 0.87 & 0.52 & 1.08 & 1.09 & 0.49 & 0.39 & 0.39 \\
\hline
\end{tabular}

Traits examined: number of stalks (NS), mean stalk weight (MSW), soluble solids content determined in field (SSF), stalk height (SH), stalk diameter (SD), tons of sugarcane per hectare (TCH), soluble solids content in laboratory (SSL), sucrose content (SC), and fiber content (FIB).

The coefficient of genetic variation $\left(\mathrm{CV}_{\mathrm{g}}\right)$ values in progenies were higher than those of clones, with the exception of FIB (Table 2). In an experiment using molecular RAPD and EST-SSR markers in inbred sugarcane progenies, Dutra Filho et al. (2012) found higher genetic variation within inbred progenies than among clones (RB clones). These authors attributed the low variability among clones to successive cycles of selection and recombination throughout the breeding program.

The TCH means were 127.24 and 108.27 t/ha in progenies and clones, respectively, and a decrease in the overall yield was observed when clones where selfed (Table 2). In a study with progenies resulting from different types of crosses, Ferreira et al. (2005) observed an overall mean of $124.6 \mathrm{t} / \mathrm{ha}$ in populations of biparental crosses, $116.42 \mathrm{t} / \mathrm{ha}$ in populations of polycrosses, and $75.70 \mathrm{t} / \mathrm{ha}$ in inbred progenies. The observed values for coefficients of relative variation $\left(\mathrm{CV}_{\mathrm{g}} / \mathrm{CV}_{\mathrm{e}}\right)$ in the progenies indicated the possibility of advantageous selection for $\mathrm{SD}, \mathrm{NS}, \mathrm{MSW}$, and $\mathrm{TCH}$, since the observed values were higher than one unit (Vencovsky and Barriga, 1992; Cruz and Regazzi, 1997). Moreover, heritability values were higher than 0.8 (Table 2). Heritability estimates in progenies ranged from 51.04 to $89.82 \%$, while clone heritability estimates were between 0.00 and $81.85 \%$. This result was due to higher genetic variance among progenies, which was expected because genetic variation among clones was 
low. However, the variation in the progenies was optimized by the segregation caused by recombination after selfing (Table 2). Interestingly, the negative heritability values for SH and SSL were 0.00, indicating low genetic variance estimates (Lynch and Walsh, 1998) (Table 2).

The FIB mean increased in seven of the eight evaluated selfed progenies. RB $867515 \otimes$ $\mathrm{RB} 739359 \otimes, \mathrm{SP} 801816 \otimes, \mathrm{RB} 928064 \otimes$, and $\mathrm{RB} 855536 \otimes$ were assigned to a group with higher means than their clones, whereas the performance of the other progenies was similar to that of their clones (Table 3). The data associated with selfed progenies that were published by Dutra Filho et al. (2011) indicated that the progeny FIB mean also increased, which reinforced the hypothesis of additive genetic variance predominance in the control of FIB.

Table 3. Mean values of progenies and clones (treatments) for the examined traits.

\begin{tabular}{|c|c|c|c|c|c|c|c|c|c|}
\hline Treatment & NS & MSW & SSF & SH & SD & $\mathrm{TCH}$ & SSL & $\mathrm{SC}$ & FIB \\
\hline RB925345 & $5.10^{\mathrm{a}}$ & $1.66^{\mathrm{a}}$ & $21.24^{\mathrm{a}}$ & $2.32^{\mathrm{a}}$ & $2.80^{\mathrm{a}}$ & $91.96^{\mathrm{a}}$ & $20.14^{\mathrm{a}}$ & $15.38^{\mathrm{a}}$ & $11.68^{\mathrm{a}}$ \\
\hline RB925345@ & $4.34^{\mathrm{b}}$ & $1.37^{\mathrm{a}}$ & $19.15^{\mathrm{b}}$ & $2.22^{\mathrm{a}}$ & $2.57^{\mathrm{b}}$ & $81.51^{\mathrm{a}}$ & $18.77^{\mathrm{b}}$ & $13.59^{\mathrm{b}}$ & $11.07^{\mathrm{a}}$ \\
\hline RB867515 & $4.61^{\mathrm{a}}$ & $1.81^{\mathrm{a}}$ & $20.41^{\mathrm{a}}$ & $2.30^{\mathrm{a}}$ & $2.96^{\mathrm{a}}$ & $90.29^{\mathrm{a}}$ & $19.26^{\mathrm{a}}$ & $14.85^{\mathrm{a}}$ & $10.10^{\mathrm{b}}$ \\
\hline RB867515@ & $3.99^{\mathrm{b}}$ & $1.51^{\mathrm{a}}$ & $19.11^{\mathrm{b}}$ & $2.35^{\mathrm{a}}$ & $2.74^{\mathrm{a}}$ & $66.51^{b}$ & $18.26^{\mathrm{b}}$ & $13.65^{\mathrm{b}}$ & $11.00^{\mathrm{a}}$ \\
\hline RB739359 & $4.60^{\mathrm{a}}$ & $1.58^{\mathrm{a}}$ & $20.15^{\mathrm{a}}$ & $2.21^{\mathrm{a}}$ & $3.09^{\mathrm{a}}$ & $78.61^{\mathrm{a}}$ & $19.64^{\mathrm{a}}$ & $15.42^{\mathrm{a}}$ & $9.43^{\mathrm{b}}$ \\
\hline RB739359® & $4.30^{\mathrm{b}}$ & $1.30^{\mathrm{a}}$ & $18.61^{\mathrm{b}}$ & $2.04^{\mathrm{b}}$ & $2.67^{\mathrm{b}}$ & $63.51^{\mathrm{b}}$ & $18.23^{\mathrm{b}}$ & $13.54^{\mathrm{b}}$ & $10.63^{\mathrm{a}}$ \\
\hline SP80-1816 & $4.55^{\mathrm{a}}$ & $1.69^{\mathrm{a}}$ & $20.84^{\mathrm{a}}$ & $2.32^{\mathrm{a}}$ & $2.90^{\mathrm{a}}$ & $83.18^{\mathrm{a}}$ & $20.06^{\mathrm{a}}$ & $15.90^{\mathrm{a}}$ & $10.14^{b}$ \\
\hline SP801816@ & $3.14^{\mathrm{c}}$ & $0.86^{\mathrm{b}}$ & $19.22^{\mathrm{b}}$ & $1.89^{\mathrm{b}}$ & $2.27^{\mathrm{c}}$ & $29.52^{\mathrm{c}}$ & $19.03^{\mathrm{a}}$ & $14.11^{\mathrm{b}}$ & $10.96^{\mathrm{a}}$ \\
\hline RB928064 & $4.57^{\mathrm{a}}$ & $1.54^{\mathrm{a}}$ & $20.80^{\mathrm{a}}$ & $2.17^{\mathrm{a}}$ & $2.89^{\mathrm{a}}$ & $76.51^{\mathrm{a}}$ & $19.51^{\mathrm{a}}$ & $15.35^{\mathrm{a}}$ & $10.27^{\mathrm{b}}$ \\
\hline RB928064® & $4.77^{\mathrm{a}}$ & $1.23^{\mathrm{b}}$ & $19.32^{\mathrm{b}}$ & $2.04^{\mathrm{b}}$ & $2.63^{\mathrm{b}}$ & $72.40^{\mathrm{a}}$ & $19.33^{\mathrm{a}}$ & $14.36^{\mathrm{a}}$ & $10.96^{\mathrm{a}}$ \\
\hline RB865230 & $5.35^{\mathrm{a}}$ & $1.43^{\mathrm{a}}$ & $20.80^{\mathrm{a}}$ & $2.26^{\mathrm{a}}$ & $2.88^{\mathrm{a}}$ & $82.97^{\mathrm{a}}$ & $19.07^{\mathrm{a}}$ & $14.59^{\mathrm{a}}$ & $9.42^{\mathrm{b}}$ \\
\hline RB865230® & $5.11^{\mathrm{a}}$ & $0.97^{\mathrm{b}}$ & $17.26^{\mathrm{c}}$ & $2.25^{\mathrm{a}}$ & $2.42^{\mathrm{c}}$ & $56.09^{\mathrm{b}}$ & $17.96^{\mathrm{b}}$ & $12.92^{\mathrm{b}}$ & $9.76^{\mathrm{b}}$ \\
\hline RB855536 & $4.82^{\mathrm{a}}$ & $1.69^{\mathrm{a}}$ & $20.08^{\mathrm{a}}$ & $2.23^{\mathrm{a}}$ & $2.93^{\mathrm{a}}$ & $88.28^{\mathrm{a}}$ & $19.30^{\mathrm{a}}$ & $14.84^{\mathrm{a}}$ & $10.31^{\mathrm{b}}$ \\
\hline RB855536® & $4.11^{\mathrm{b}}$ & $1.06^{\mathrm{b}}$ & $19.49^{\mathrm{b}}$ & $2.13^{\mathrm{a}}$ & $2.40^{\mathrm{c}}$ & $48.12^{c}$ & $18.54^{\mathrm{b}}$ & $13.78^{\mathrm{b}}$ & $10.86^{\mathrm{a}}$ \\
\hline RB943365 & $4.32^{\mathrm{b}}$ & $1.37^{\mathrm{a}}$ & $20.03^{\mathrm{a}}$ & $2.15^{\mathrm{a}}$ & $2.75^{\mathrm{a}}$ & $64.27^{\mathrm{b}}$ & $19.40^{\mathrm{a}}$ & $15.46^{\mathrm{a}}$ & $9.40^{\mathrm{b}}$ \\
\hline RB943365® & $4.78^{\mathrm{a}}$ & $0.96^{\mathrm{b}}$ & $17.27^{\mathrm{c}}$ & $1.96^{\mathrm{b}}$ & $2.49^{\mathrm{b}}$ & $48.34^{\mathrm{c}}$ & $17.24^{\mathrm{b}}$ & $12.50^{\mathrm{b}}$ & $10.23^{\mathrm{b}}$ \\
\hline
\end{tabular}

Traits examined: number of stalks (NS), mean stalk weight (MSW), soluble solids content determined in field (SSF), stalk height (SH), stalk diameter (SD), tons of sugarcane per hectare $(\mathrm{TCH})$, soluble solids content determined in laboratory (SSL), sucrose content (SC), and fiber content (FIB). Means with the same letter in the column belong to the same group (according to the Scott-Knott test at 5\% probability).

Regarding NS, the Scott-Knott test formed three groups, and only SP80-1816 $\otimes$ was in the third group because it exhibited the poorest performance with a mean of 3.14 stalks/ plant (Table 3). According to Pedrozo et al. (2008), to optimize the efficiency in the initial phase of the breeding program, genotypes with less than five stalks should be discarded during individual selection during T1 even if the other traits are favorable for selection. The NS means of all clones were affected by selfing, and this decreased the tillering capacity of all progenies compared to the parent.

Two MSW groups were formed, and the MSW values of the clones that remained in the first group were between 1.30 and $1.81 \mathrm{~kg}$. Only SP80-1816 $\otimes$ and RB928064 $\otimes$ were assigned to the second group (with means of 0.86 and $1.23 \mathrm{~kg}$, respectively). Due to inbreeding effects, the MSW of SP80-1816 $\otimes$ was only half of that observed in its parent (Table 3). The MSW results were in agreement with the results of Ferreira et al. (2005) and Silva and Gonçalves (2011), which also indicated a reduction in the MSW mean due to selfing.

Two SSL groups were formed, and the means ranged between 20.03 and $20.84 \%$ in the first group, which consisted of clones only. The second group was formed by progenies, and mean values ranged between 17.24 and $19.33 \%$ (Table 3). SSF was divided into three groups, and the mean values of the first group (containing clones and the SP80-1816 $\otimes$ and 
RB928064® progenies) varied from 19.03 to $20.14 \%$. Silva and Gonçalves (2011) reported values between 14.5 to $19.9 \%$ to for SSL, but the authors found that some selfed progenies had higher means than their clones.

Regarding SH (Table 3), two groups were formed, and RB928064 $\otimes$, SP80-1816 $\otimes$, $\mathrm{RB} 739359 \otimes$, and $\mathrm{RB} 943365 \otimes$ progenies were allocated in the second group (mean values from 1.89 to $2.04 \mathrm{~m}$ ). The other treatments were assigned to the first group (means values from 2.13 to $2.35 \mathrm{~m}$ ). Silva and Gonçalves (2011) found that SH values were reduced in relation to the respective clones in all selfed sugarcane progenies evaluated in their study.

Considering the observed SD mean (Table 3), three groups were formed, and the first group included all of the clones and $\mathrm{RB} 867515 \otimes$. The mean SD of the first group ranged from 2.74 to $3.09 \mathrm{~cm}$, and the second group consisted of $\mathrm{RB} 925345 \otimes, \mathrm{RB} 739359 \otimes, \mathrm{RB} 928064 \otimes$, and RB943365 $\otimes$ (mean values between 2.49 and $2.67 \mathrm{~cm}$ ). The third group contained SP80-1816 $\otimes$, $\mathrm{RB} 865230 \otimes$, and $\mathrm{RB} 855536 \otimes$, and the SD means ranged from 2.27 to $2.42 \mathrm{~cm}$, with reduced SD in the progenies. Silva and Gonçalves (2011) also observed lower SD values in inbred progenies.

Two SC groups were formed, and the means of the first group (including all clones and progeny $\mathrm{RB} 928064 \otimes$ ranged from 14.36 to $15.90 \%$. The other treatments were assigned to the second group (Table 3). Dutra Filho et al. (2011) reported a similar behavior in clones and their respective progenies, and a reduction in progeny SC mean values were observed. Regarding FIB, the behavior of mean values differed from those observed in the previous grouping in that the progenies and clone RB925345 had the highest means (from 10.86 to $11.68 \%$ ), and only progeny RB943365 $\otimes$ was excluded from the first group (Table 3).

Regarding TCH, the treatments were separated into three groups, and the first group exhibited means between 72.40 and $91.96 \mathrm{t} / \mathrm{ha}$, which included all clones (except RB943365) and progenies $\mathrm{RB} 925345 \otimes$ and $\mathrm{RB} 928064 \otimes$. RB $925345 \otimes$ performed best among the progenies $(81.51 \mathrm{t} / \mathrm{ha})$, and its performance was also better than clones RB739359, RB928064, and RB943365. Dutra Filho et al. (2011) found that even with the yield reduction caused by selfing, some families had better performance than their clones.

The effect of inbreeding on the TCH mean values of progenies was clear, and this was indicated by the larger discrepancies in mean values between progenies and clones. Compared to their respective parents, the yield of progenies was not reduced in any case. The progenies with greatest reductions in trait means were SP80-1816 $\otimes, \mathrm{RB} 855536 \otimes, \mathrm{RB} 865230 \otimes$, and RB $867515 \otimes$, and those least affected by inbreeding were RB925345 and RB928064 $\otimes$ (Table 3). Hogarth (1980), Bastos et al. (2003), and Ferreira et al. (2005) observed a decrease in mean $\mathrm{TCH}$ in progenies in their studies, which was explained by dominance variance associated with dominance deviations. The RB925345 $\otimes$ and $\mathrm{RB} 928064 \otimes$ progenies performed well for TCH and other traits. Furthermore, RB925345 $\otimes$ exhibited good mean values for MSW, SH, and FIB, and RB928064 $\otimes$ demonstrated good performance for NS, SC, and FIB (Table 3).

SP80-1816 $\otimes$ had the lowest percentage of superior plants for SH (15.49\%), NS $(19.86 \%)$, and SD (3.57\%). Regarding overall performance (OP), RB943365 $\otimes)$, RB865230® and SP80-1816 $\otimes$ had the poorest results (Table 4).

The percentage of superior plants was highest in $\mathrm{RB} 867515 \otimes(57.55 \%)$ for $\mathrm{SH}$, and it was second best for SD (28.67\%). The highest percentages of superior plants for SD (31.85\%) and NS (52.11\%) were observed in RB925345 $\otimes$ and RB943365 $\otimes$, respectively. In terms of overall performance, the best progenies were RB739359 $\otimes(1), \mathrm{RB} 867515 \otimes(1), \mathrm{RB} 925345 \otimes$ (1), and RB928064® (2) (Table 4). 
Table 4. Number of seedlings (NS), progeny and clone means (M), percentage of the number of clones superior to their progenies (S1 Sup. (\%)), trait ranking (R), sum of ranks (SR), and overall performance (OP) for the examined traits.

\begin{tabular}{|c|c|c|c|c|c|c|c|c|c|c|c|c|c|c|c|}
\hline \multirow[t]{2}{*}{ Treatments } & \multirow[t]{3}{*}{ NS } & \multicolumn{3}{|c|}{ SH } & \multicolumn{3}{|c|}{ SSF } & \multicolumn{3}{|c|}{ NS } & \multicolumn{3}{|c|}{ SD } & \multirow[t]{2}{*}{ SR } & \multirow[t]{2}{*}{ OP } \\
\hline & & $\mathrm{M}$ & S1 Sup. (\%) & $\mathrm{R}$ & $\mathrm{M}$ & S1 Sup. (\%) & $\mathrm{R}$ & $\mathrm{M}$ & S1 Sup. (\%) & $\mathrm{R}$ & $\mathrm{M}$ & S1 Sup. (\%) & $\mathrm{R}$ & & \\
\hline RB925345 & & 2.32 & & & 21.24 & & & 5.10 & & & 2.80 & & & & \\
\hline RB925345® & 151 & 2.22 & 41.72 & 4 & 19.15 & 12.10 & 6 & 4.34 & 33.54 & 7 & 2.57 & 31.85 & 1 & 22 & 2 \\
\hline RB867515 & & 2.30 & & & 20.41 & & & 4.61 & & & 2.96 & & & & \\
\hline RB867515® & 139 & 2.35 & 57.55 & 1 & 19.11 & 25.17 & 5 & 3.99 & 37.76 & 6 & 2.74 & 28.67 & 2 & 15 & 1 \\
\hline RB739359 & & 2.21 & & & 20.15 & & & 4.60 & & & 3.09 & & & & \\
\hline RB739359® & 136 & 2.04 & 47.79 & 2 & 18.61 & 28.28 & 2 & 4.30 & 42.86 & 4 & 2.67 & 17.01 & 5 & 15 & 1 \\
\hline SP80-1816 & & 2.32 & & & 20.84 & & & 4.55 & & & 2.90 & & & & \\
\hline SP80-1816 $\otimes$ & 140 & 1.89 & 15.49 & 8 & 19.22 & 25.53 & 4 & 3.14 & 19.86 & 8 & 2.27 & 3.57 & 8 & 36 & 6 \\
\hline RB928064 & & 2.17 & & & 20.80 & & & 4.57 & & & 2.89 & & & & \\
\hline RB928064® & 140 & 2.04 & 42.14 & 3 & 19.32 & 26.58 & 3 & 4.77 & 46.20 & 3 & 2.63 & 25.32 & 3 & 15 & 1 \\
\hline RB865230 & & 2.26 & & & 20.80 & & & 5.35 & & & 2.88 & & & & \\
\hline RB $865230 \otimes$ & 137 & 2.25 & 37.23 & 6 & 17.26 & 7.48 & 8 & 5.11 & 41.09 & 5 & 2.42 & 9.59 & 7 & 32 & 5 \\
\hline RB855536 & & 2.23 & & & 20.08 & & & 4.82 & & & 2.93 & & & & \\
\hline RB855536® & 139 & 2.13 & 41.01 & 5 & 19.49 & 38.73 & 1 & 4.11 & 52.11 & 2 & 2.40 & 9.86 & 6 & 19 & 3 \\
\hline RB943365 & & 2.15 & & & 20.03 & & & 4.32 & & & 2.75 & & & & \\
\hline RB943365® & 131 & 1.96 & 23.66 & 7 & 17.27 & 8.89 & 7 & 4.78 & 54.82 & 1 & 2.49 & 23.70 & 4 & 26 & 4 \\
\hline S1Sup. (\%)MED & & & 38.32 & & & 21.60 & & & 41.03 & & & 18.70 & & & \\
\hline
\end{tabular}

Traits examined: mean stalk length (SH), soluble solids content in field (SSF), number of stalks (NS), and mean stalk diameter (SD).

Table 4 shows that, in spite of the statistically lower means of the progenies compared to their clones for most traits (Table 2), transgressive plants could be identified based on the individual behavior within plots compared to the means of the respective clones. Although genotypes with higher accumulations of favorable alleles that exhibited behavior equal or superior to their clones could be found in all progenies, the progeny mean values were penalized by the high number of plants with large amounts of deleterious alleles.

The percentage of inbreeding depression for NS was highest in SP80-1816 $\otimes$, but the percentage was negative for $\mathrm{RB} 928064 \otimes$ and $\mathrm{RB} 943365 \otimes$, indicating that selfing induced vigor for NS in these progenies (Table 5). Regarding MSW, the inbreeding depression between progeny mean values varied between $16.88 \%$ and $49.20 \%$, indicating that all progeny mean values were affected. SP80-1816 $\otimes$ had the highest inbreeding depression for MSW, and $\mathrm{RB} 867515 \otimes$ exhibited the lowest inbreeding effects (Table 5).

Regarding SH, the ID value of SP80-1816® was highest. Moreover, the ID value of $\mathrm{RB} 865230 \otimes$ was close to zero, while $\mathrm{RB} 867515 \otimes$ had low vigor $(-2.44 \%)$. For $\mathrm{SD}$, the percentage of ID ranged from $7.41 \%$ to $21.89 \%$. Similar to SH, the progenies with the best and the worst behaviors were $\mathrm{RB} 867515 \otimes$ and $\mathrm{SP} 80-1816 \otimes$, respectively (Table 5).

The mean ID for TCH was $28.67 \%$, which was the highest ID of all traits. The percentage of ID for TCH was highest for SP80-1816® $(64.51 \%)$ and lowest for RB928064 $\otimes$ (5.13\%) (Table 5). The results of Jenkins (1935) and Maluf et al. (2001), which examined different crops, indicated that high ID levels could be restored by recombination.

The ID percentages for SSL were between 0.95 and $11.12 \%$ (mean of $5.77 \%$ ), and the lowest and highest values were associated with RB928065 $\otimes$ and RB943364 $\otimes$ respectively (Table 5). SSL had the second lowest ID mean, which indicated the predominance of additive effects on trait control, which was suggested by Bastos et al. (2003) when evaluating the agronomic traits of sugarcane in a diallel analysis. Hogarth (1980), Cassalett et al. (1995), and Ferreira et al. (2005) observed that the soluble solids content was least affected by ID. According to Husband and Schemske (1997), polyploid plants would likely have lower ID, and polyploidy could mitigate the disadvantages caused by selfing (Rausch and Morgan, 2005).

Regarding SC, ID percentages varied between 6.48 and $19.13 \%$, indicating that 
$\mathrm{RB} 943365 \otimes$ and $\mathrm{RB} 928064 \otimes$ were the best and the worst performing progenies, respectively (Table 5). FIB was the only trait with an overall mean ID that indicated an improved progeny mean. Regarding OP, only RB925345 $\otimes$ had positive FIB values, and the other progenies showed vigor when compared with their respective clones, indicating selfing as a possible strategy to increase sugarcane FIB. Of all of the progenies, the vigor for FIB was highest in $\mathrm{RB} 867515 \otimes(\mathrm{ID}=-12.74 \%)$ (Table 5). Qijun et al. (1998) studied the inheritance of sugarcane biomass content, and they concluded that FIB was controlled by additive and non-additive effects. However, a predominance of additive effects were also involved.

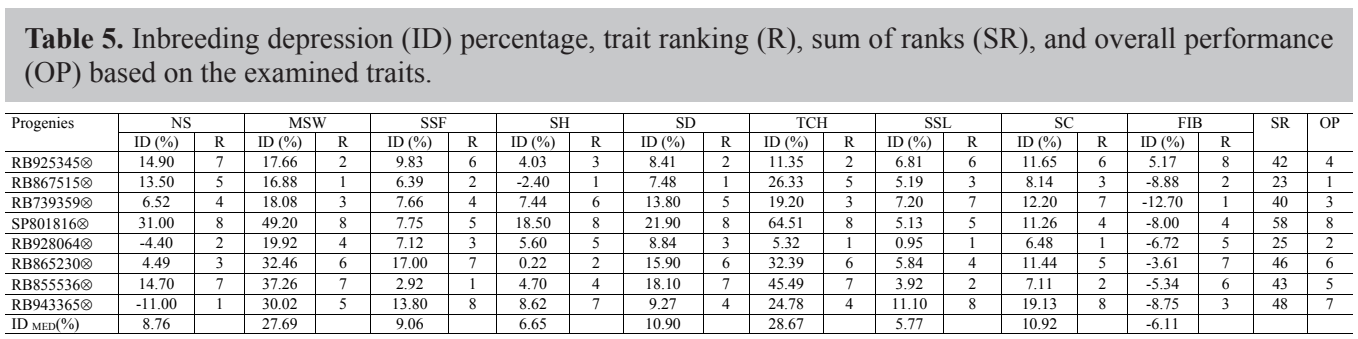

Traits examined: number of stalks (NS), mean stalk weight (MSW), soluble solids content in field (SSF), stalk height $(\mathrm{SH})$, mean stalk diameter (SD), tons of sugarcane per hectare (TCH), soluble solids content determined in laboratory (SSL), sucrose content (SC), and fiber content (FIB).

According to Silva and Gonçalves (2011), traits with additive gene effects are theoretically improvable using the selection of superior genotypes in inbred progenies, and this also provides information regarding the effect of ID on agronomic traits of interest.

In terms of $\mathrm{OP}, \mathrm{RB} 867515 \otimes, \mathrm{RB} 928064 \otimes, \mathrm{RB} 739359 \otimes$, and $\mathrm{RB} 925345 \otimes$ exhibited the best performance (Table 5). Although there were differences in the ranking, the four best progenies in terms of the number of superior progenies were the same as those least affected by ID (i.e., progenies with the highest number of transgressive progenies had a higher overall mean than their respective parent, implying lower ID) (Tables 4 and 5). Based on the results shown in Tables 4 and 5 , the focus of selection should be on RB867515 $\otimes$, RB928064 $\otimes$, $\mathrm{RB} 739359 \otimes$, and $\mathrm{RB} 925345 \otimes$.

In selection schemes using inbred progenies, there is greater selection pressure against deleterious genes, and improved progenies from these populations produce genotypes with reduced ID (Hallauer, 1980). Thus, there is the possibility of reducing the population genetic load when selecting transgressive plants in the selfed population.

Since plants with lower vigor were eliminated, a sugarcane progeny derived from a cross between clones selected from inbred progenies will have a lower ID than a progeny derived from clones selected from half-sib or full-sib progenies. This is because a major portion of the deleterious alleles expressed in the previous generation were eliminated (S1).

Mass selection was applied in the initial population of 1113 seedlings (T1), which led to the 30 genotypes of T2. Mass selection was only effective in $\mathrm{RB} 867515 \otimes, \mathrm{RB} 928064 \otimes$, $\mathrm{RB} 739359 \otimes, \mathrm{RB} 925345 \otimes$, and $\mathrm{RB} 943365 \otimes$ (Table 6). After the second selection cycle in $\mathrm{T} 2$, nine genotypes were advanced to T3, and the nine genotypes selected in T2 belonged to $\mathrm{RB} 867515 \otimes$, $\mathrm{RB} 928064 \otimes, \mathrm{RB} 739559 \otimes$, and $\mathrm{RB} 925345 \otimes$ (Table 6). Among the eight progenies used in T1, only four genotypes contributed to phase T3 of the breeding program, in which the progenies had the best OP and the lowest ID (Tables 4, 5, and 6). 
Table 6. Number of selected genotypes and selection indices (SI) applied to sugarcane progenies in phases $\mathrm{T} 1, \mathrm{~T} 2$, and $\mathrm{T} 3$.

\begin{tabular}{|c|c|c|c|}
\hline Progenies & $\mathrm{T} 1$ & $\mathrm{~T} 2$ & $\mathrm{~T} 3$ \\
\hline RB867515@ & 139 & 10 & 3 \\
\hline RB928064® & 140 & 7 & 1 \\
\hline RB739359® & 136 & 10 & 4 \\
\hline RB925345® & 151 & 1 & 1 \\
\hline RB943365® & 131 & 2 & 0 \\
\hline RB865230@ & 137 & 0 & 0 \\
\hline RB $855536 \otimes$ & 139 & 0 & 0 \\
\hline SP80-1816® & 140 & 0 & 0 \\
\hline TOTAL & 1113 & 30 & 9 \\
\hline SI $(\%)$ & - & 2.7 & 30 \\
\hline
\end{tabular}

Mass selection was conducted to confirm whether phenotype-based selection would agree with the estimates shown in Tables 4 and 5. Once confirmed (Table 6), breeders should first obtain the results of Tables 4 and 5, and they should then carry out selection using the best progenies to avoid selection within less promising progenies. However, a greater number of genotypes within the progenies classified with the best OP should be selected.

For breeding programs in which large numbers of progenies can be evaluated, Tables 4 and 5 allow screening by selecting the best progenies based on OP, and selection of genotypes within S1 progenies with higher means for the traits of interest is then possible. In view of the vigor observed for FIB, breeders should focus on the progenies with highest means for this trait to ultimately release "energy sugarcane" clones. Another strategy would be to initially use clones known to have high fiber content in order to obtain progenies with even higher percentages.

The genotypes selected from S1 progenies could be selfed again and/or multiplied in interpopulational crosses. Furthermore, this would allow evaluation in subsequent phases of the breeding program, and it would also provide a view into the release of new clones by an RRSI-S1 program.

\section{CONCLUSIONS}

The gene actions of the MSW and TCH traits were predominantly associated with dominance variance, and these characters were most affected by ID. The genetic control of FIB was due to additive variance, and it was not affected by selfing. Considering superior OP and the selection for yield-related traits at different phases of the breeding program, promising genotypes were derived from the RB $867515 \otimes, \mathrm{RB} 928064 \otimes, \mathrm{RB} 739359 \otimes$, and $\mathrm{RB} 925345 \otimes$ progenies. Using S1 progenies for the application of RRSI-S1 is promising for sugarcane breeding programs, and it should be exploited to breed clones with high FIB levels.

\section{Conflicts of interest}

The authors declare no conflict of interest.

\section{ACKNOWLEDGMENTS}

Research supported by Coordenação de Aperfeiçoamento de Pessoal de Nível Superior (CAPES), Fundação de Amparo à Pesquisa de Minas Gerais (FAPEMIG) and Conselho Nacional de Desenvolvimento Científico e Tecnológico (CNPq). 


\section{REFERENCES}

Bastos IT, Barbosa MHP, Cruz CD, Burnquist WL, et al. (2003). Análise dialélica em clones de cana-de-açúcar. Bragantia 62: 199-206. http://dx.doi.org/10.1590/S0006-87052003000200004

Bhering LL, Cruz CD, De Vasconcelos ES, Ferreira A, et al. (2008). Alternative methodology for Scott-Knott test. Crop Breed. Appl. Biotechnol. 8: 9-16. http://dx.doi.org/10.12702/1984-7033.v08n01a02

Cassalett C, Viveros C and Pizza L (1995). Self-pollination in sugarcane hybrids, Saccharum sp. In: XXII International Society of Sugarcane Technologists Congress, Cartagena, 312-315.

Cruz CD (2013). Genes: a software package for analysis in experimental statistics and quantitative genetics. Acta Sci. Agron. 35: 271-276. http://dx.doi.org/10.4025/actasciagron.v35i3.21251

Cruz CD and Regazzi A (1997). Modelos biométricos aplicados ao melhoramento genético, Vol. 2. Eds. Editora UFV, Viçosa.

Dutra Filho JA, de Melo LJOT, Resende LV, Anunciação Filho CJ, et al. (2011). Aplicação de técnicas multivariadas no estudo da divergência genética em cana-de-açúcar. Rev. Cienc. Agron. 42: 185-192.

Dutra Filho JA, Resende LV, Bastos GQ, Neto DES, et al. (2012). Utilização de marcadores moleculares RAPD e EST's SSR para estudo da variabilidade genética em cana-de-açúcar. Rev. Cienc. Agron. 44: 141-149.

Fernandes AC (2011). Cálculos na agroindústria da cana-de-açúcar, 3. Eds. Stab, Piracicaba.

Ferreira FM, Barbosa MHP, Castro R, Paternelli L, et al. (2005). Effects of inbreeding on the selection of sugar cane clones. Crop Breed. Appl. Biotechnol. 5: 174-182. http://dx.doi.org/10.12702/1984-7033.v05n02a07

Hallauer AR (1980). Relation of quantitative genetics to applied maize breeding. Braz. J. Genet. 3: 207-233.

Hogarth D (1980). The effect of accidental selfing on the analysis of a diallel cross with sugar cane. Euphytica 29: 737-746. http://dx.doi.org/10.1007/BF00023220

Husband BC and Schemske DW (1997). The effect of inbreeding in diploid and tetraploid populations of Epilobium angustifolium (Onagraceae): implications for the genetic basis of inbreeding depression. Evolution 51: 737-746. http://dx.doi.org/10.2307/2411150

Jenkins MT (1935). The effect of inbreeding and of selection within inbred lines of maize upon the hybrids made after successive generations of selfing. Iowa State J. Sci 3: 429-450.

Lynch M and Walsh B (1998). Genetics and analysis of quantitative traits. Vol. 1. Sinauer, Sunderland, MA.

Maluf W, Nass L, Valois A, Melo I, et al. (2001). Recursos genéticos \& melhoramento - plantas. In: Heterose e emprego de híbridos F1 em hortaliças (Maluf W, Nass L, Valois A, Melo I, et al.). Fundação MT, Rondonópolis, 237-356.

Pedrozo C, Barbosa MHP, Resende MDV, Peternelli LA, et al. (2008). Eficiência da seleção em fases iniciais do melhoramento da cana-de-açúcar. Rev. Ceres 55: 001.

Pimentel GF (1990). Curso de estatística experimental. Curso de Estatística Experimental. 12.

Qijun H, Debo L, Dengao Z and Rukai C (1998). The combining ability analysis of sugarcane breeding for biomass. Sugarcane (China) 5: 1-6.

Resende MDV (2002). Genética biométrica e estatística no melhoramento de plantas perenes. 1 Ed. Editora Embrapa, Colombo.

Resende MDV and Barbosa MHP (2005). Melhoramento genético de plantas de propagação assexuada. 1 Ed. Editora Embrapa, Colombo.

Rausch JH and Morgan MT (2005). The effect of self-fertilization, inbreeding depression, and population size on autopolyploid establishment. Evolution 59: 1867-1875.

Silva MDA and Gonçalves PDS (2011). Inbreeding in sugarcane varieties. Cienc. Rural 41: 580-586. http://dx.doi. org/10.1590/S0103-84782011005000028

Vencovsky R and Barriga P (1992). Genética biométrica no fitomelhoramento. 1 Ed. Editora Revista Brasileira de Genética, Ribeirão Preto. 